\title{
Study of Parasitic Pathogens on Nigerian Currency Circulating in Selected Markets in Lafia Metropolis, Nasarawa State, Nigeria
}

\author{
Pam V A ${ }^{1}$, Attah A S ${ }^{1 *}$, Uzoigwe $\mathrm{N} \mathrm{R}^{1}$, Ombugadu $\mathrm{A}^{1}$, Omalu I C J ${ }^{2}$, Ahmed H $\mathbf{0}^{1}$, Aimankhu P $0^{1}$, \\ Maikenti J I ${ }^{1}$, Yina G $\mathrm{I}^{3}$ and Okeke $\mathrm{P}^{4}$ \\ ${ }^{1}$ Department of Zoology, Faculty of Science, Federal University of Lafia, Lafia, Nasarawa State, Nigeria
}

${ }^{2}$ Department of Animal Biology (Parasitology and Tropical Diseases Research Unit), Federal University of Technology, Minna, Niger State, Nigeria

${ }^{3}$ Department of Zoology, Faculty of Natural Sciences, University of Jos, Jos, Plateau State, Nigeria

${ }^{4}$ Faculty of Natural and Applied Sciences, Godfrey Okoye University, Enugu, Enugu State, Nigeria

*Corresponding author: Attah A S, Department of Zoology, Faculty of Science, Federal University of Lafia, Lafia, Nasarawa State,

Nigeria, E-mail: sylvesterattah113@gmail.com

\section{ARTICLE INFO}

Received: March 04, 2021

Published: 幽 March 10, 2021

Citation: Pam V A, Attah A S, Uzoigwe N R, Ombugadu A, Omalu I C J, et al. Study of Parasitic Pathogens on Nigerian Currency Circulating in Selected Markets in Lafia Metropolis, Nasarawa State, Nigeria. Biomed J Sci \& Tech Res 34(3)-2021. BJSTR. MS.ID.005557.

Keywords: Parasites; Circulating Naira Currency; Lafia Metropolis; Selected Markets; Currency Sources; Paper and Polymer Notes

\begin{abstract}
Money is the most widely handled article throughout the world, it goes through clean and dirty hands and can get contaminated with parasites and pathogens. Thus, the study on parasites associated with circulating Naira notes in selected markets in Lafia metropolis, Nasarawa State, Nigeria was carried out from June, 2019 to March, 2020. A total of three hundred and twenty (320) samples of Nigerian Naira notes consisting of forty (40) pieces of each denomination was used for this study. Market samples were collected from food vendors, fish sellers, butchers, hawkers and fruits/vegetable sellers and then screened. Out of the 320 samples examined, $32(10.00 \%)$ were contaminated with parasite species that spread across Ascaris lumbricoides $6(1.88 \%)$, Entamoeba histolytica 7 (2.19\%), hookworm 10 (3.13\%), Taenia spp. $1(0.31 \%)$ and Trichuris trichiura $8(2.50 \%)$. The mint Naira notes had no parasitic contamination. The level of parasitic contamination of Naira notes in relation to currency sources, and as well as the physical conditions of the notesshowed a very high significant difference $(\mathrm{P}<0.001)$. Also, parasitic contamination in relation to Naira notes denominations showed a very high significant difference $(\mathrm{P}<0.001)$. Only the paper notes were contaminated with human pathogenic parasites while polymer notes were parasite free. In conclusion, this is the first study in Lafia, Nasarawa State that showed that the Nigerian currency notes in circulation within the metropolis are contaminated with five parasite species that are known to be pathogenic to humans. Also, the handlers of such Naira notes may possibly stand a chance of being infected with the parasites recorded if their hands are not properly washed and sanitized after transactions.
\end{abstract}

\section{Introduction}

Money, in the form of currency notes and coins, is extensively traded for goods and services in countries all over the world. Perhaps, it is the most widely handled article throughout the world; being exchanged by several hands each day [1]. Money goes through clean and dirty hands and can get contaminated with parasites and pathogens [2]. Previous studies conducted in different parts of the world shows that currency notes are common vehicles for pathogenic transmission of diseases [3-10]. They reported that ova and larvae belong to different species of microsporidia, cryptosporidium, Taenia, Trichuris, Enterobius, Amoeba and Ascaris. All of the reported parasites are known enteric pathogens. In Nigeria, the currency is highly abused and can be commonly 
seen faded, torn, stapled, cello taped, squeezed and with writings on them. Being the most frequently passed item in the world it should not come as a surprise as these currency notes are usually contaminated with various pathogens and parasitic organisms as it is handled by persons of varying health and hygienic standards and is stored under varying environmental and personal hygienic conditions [11]. Awodi et al. [12] reported that the major source of currency contamination in Nigeria could be as a result of poor or negative money handling practices like spraying during ceremonies, here the notes are sprayed on the celebrant(s) and in the process fall on the ground where a large number of people dancing, step on them with soiled shoes which are often contaminated with parasites or pathogens.

Parasites that have been observed to be contaminants of the naira notes are mainly of faecal origin [12]. Generally, lack of personal hygiene is one of the common ways to contaminate the currency notes with parasitic pathogens. Unhygienic habit such as improperly washing of hands after visiting the toilets as well as the habit of wetting fingers with saliva during money counting to a greater extend leads to the contamination of these currency notes with cysts, eggs and larvae of pathogenic parasites [3-10]. In view of the above, the study aimed at isolating and identifying parasitic pathogens contaminating circulating Nigerian naira notes in selected markets in Lafia metropolis, Nasarawa State, Nigeria.

\section{Materials and Methods}

\section{Study Area}

The study was carried out in Lafia metropolis, Nasarawa State, Nigeria. The city of Lafia is the administrative headquarter of Lafia local government and the administrative capital of Nasarawa State, Nigeria. Lafia has a population of about 127,236 inhabitants and is situated on latitude $8.48^{\circ}$ North, Longitude $8.52^{\circ}$ East and 290 meters elevation above the sea level [13]. Lafia metropolis is about $100 \mathrm{~km}$ (straight distance) from the Federal capital city Abuja and approximately southeast (SE) from the federal capital territory (FCT) [14]. Lafia serves as a higher-order city in the provision of consumer goods and other services to the immediate smaller towns that are directly linked to it. A number of banks including first and second generation banks are operational in the city as business activities are high.

\section{Collection of Samples}

A total of three hundred and eighty-four (320) samples of Nigerian currency notes consisting of forty-eight (40) pieces of each naira note denominations ( $\$ 5, \$ 10, \$ 20, \$ 50, \$ 100, \$ 200$, $\$ 500$, and $\$ 1000$ ) of both polymer and paper were randomly collected for the purpose of this research from June 2019 to March 2020. Verbal consent of the participants was obtained before the collection and exchange of the notes. Naira notes were collected from two (2) markets (Lafia modern market, and Alamis market) selected within Lafia metropolis. In the market, samples were collected from food vendors, fish sellers, butchers, hawkers, fruits and vegetable sellers. The naira notes were collected aseptically, kept separately in a labelled sterile polythene bags and conveyed to the Department of Zoology laboratory of the Federal University of Lafia for screening. The notes were grouped as follows: Mints, dirty, very dirty and mutilated dirty. The mints notes served as control.

\section{Parasitological Screening}

The parasitological screening was carried out according to the methods outlined by Leonard and Olajumoke [7] and Ahmed and Mujittapha [8]. Each group of the identified currencies within the selected denominations were inserted into a sterile bottle containing $20 \mathrm{ml}$ of normal saline. The bottle was vigorously shaken and left standing for 30 minutes, then shaken all over again for the last time. The Naira notes were then removed using a pair of sterile forceps and transferred into a sterile polythene bag. The contents of each bottle were poured into centrifuge tubes and centrifuged at $1000 \mathrm{rpm}$ for 5 minutes. The supernatant was carefully decanted, while the resultant sediment was stirred, and a drop placed on a clean grease-free glass slide and then covered with a glass cover slip. The slide was then examined microscopically under x10 and x40 magnifications for presence of parasite cysts, eggs and larvae.

\section{Statistical Analysis}

Data obtained were analysed using R Console software (Version 3.2.2). Pearson's Chi-square test was used to compare prevalence rate between species of parasites. Also, prevalence of parasites in relation to currency denominations, currency sources and as well as the physical conditions of the currency was compared using Pearson's Chi-square test. Level of significance was set at $\mathrm{P}<0.05$.

\section{Results}

\section{Composition and Prevalence of Parasites on Naira Notes Collected from Markets in Lafia, Nasarawa State, Nigeria}

Out of the 320 currency notes analyzed for parasitological contamination, $32(10.00 \%)$ were observed to be contaminated with parasites as shown in (Table 1). The most dominant parasite was hookworm 10 (3.13\%) followed by Trichuris trichiura 8 (2.50\%) then Entamoeba histolitica 7 (2.19\%), Ascaris lumbricoides $6(1.88 \%)$ while the least was Taenia spp. 1 (0.31\%). However, the prevalence rate in relation to the parasite species showed no significant difference $\left(X^{2}=22.2145, \mathrm{df}=4, \mathrm{P}=0.6964\right)$.

Table 1: Checklist of parasites isolated from Naira currency collected from markets in Lafia, Nasarawa State, Nigeria $(n=320)$.

\begin{tabular}{|c|c|}
\hline Species & No. of N currency notes contaminated (\%) \\
\hline Ascaris lumbricoides & $6(1.88)$ \\
\hline Entamoeba histolitica & $7(2.19)$ \\
\hline Hookworm & $10(3.13)$ \\
\hline Taenia spp. & $1(0.31)$ \\
\hline Trichuris trichiura & $8(2.50)$ \\
\hline Total (\%) & $\mathbf{3 2}(\mathbf{1 0 . 0 0 )}$ \\
\hline
\end{tabular}


Prevalence of Parasites in Relation to Currency Physical Conditions

From (Table 2), no parasites were found to contaminate the mint (control) Naira notes. However, very dirty Naira notes had the highest parasitic contamination of 13 (16.25\%) followed by the mutilated dirty notes $11(13.75 \%)$ and dirty naira notes 8 $(10.00 \%)$. Therefore, there was a high significant difference $\left(\chi^{2}=\right.$ $15.312, \mathrm{df}=3, \mathrm{P}=0.001568$ ) in the parasitic contamination of Naira notes in relation to physical conditions.

Table 2: Parasitic contamination of Naira notes in relation to their physical conditions.

\begin{tabular}{|c|c|c|c|c|c|}
\hline \multirow[b]{2}{*}{ Species } & \multicolumn{4}{|c|}{ Conditions of currency notes } & \multirow{2}{*}{$\begin{array}{c}\text { Total No. } \\
n=320\end{array}$} \\
\hline & $\begin{array}{c}\text { Mint (Control) } \\
n=80\end{array}$ & $\begin{array}{c}\text { Dirty } \\
n=80\end{array}$ & $\begin{array}{c}\text { Very dirty } \\
\mathbf{n}=\mathbf{8 0}\end{array}$ & $\begin{array}{l}\text { Mutilated dirty } \\
\quad \mathbf{n}=\mathbf{8 0}\end{array}$ & \\
\hline Ascaris lumbricoides & $0(0.00)$ & $2(2.50)$ & $3(3.75)$ & $3(3.75)$ & $8(2.50)$ \\
\hline Entamoeba histolitica & $0(0.00)$ & $1(1.25)$ & $4(5.00)$ & $1(1.25)$ & $6(1.88)$ \\
\hline Hookworm & $0(0.00)$ & $3(3.75)$ & $2(2.50)$ & $5(6.25)$ & $10(3.13)$ \\
\hline Taenia spp. & $0(0.00)$ & $2(2.50)$ & $3(3.75)$ & $2(2.50)$ & $7(2.19)$ \\
\hline Trichuris trichiura & $0(0.00)$ & $0(0.00)$ & $1(1.25)$ & $0(0.00)$ & $1(0.31)$ \\
\hline Total (\%) & $0(0.00)$ & $8(10.00)$ & $13(16.25)$ & $11(13.75)$ & $32(10.00)$ \\
\hline
\end{tabular}

\section{Prevalence of Parasites in Relation to Currency Denominations and Types of Notes}

The hundred-naira ( $\$ 100)$ denomination had the highest parasitic contamination rate $12(30.00 \%)$ followed by $\$ 20010$ (25.00\%), then $\$ 5007$ (17.50\%), $\$ 10003$ (7.50\%) while $\$ 5$, $\$ 10$, \#20 and $\$ 50$ were not parasitized (Table 3). Thus, there was a very high significant difference $\left(\chi^{2}=108.75, \mathrm{df}=7, \mathrm{P}<0.0001\right)$ in parasitic contamination in relation to denominations of notes. Of all the polymer notes screened, none was found to be contaminated with parasite while at least three notes and above from each of the paper notes denominations were contaminated (Table 3).

Table 3: Prevalence of parasites in relation to currency denominations and types of notes.

\begin{tabular}{|c|c|c|c|}
\hline $\begin{array}{c}\text { Naira currency } \\
\text { denomination } \\
\text { (N) }\end{array}$ & Note type & No. examined & $\begin{array}{c}\text { No. } \\
\text { contaminated } \\
\text { (\%) }\end{array}$ \\
\hline 5 & Polymer & 40 & $0(0.00)$ \\
\hline 10 & Polymer & 40 & $0(0.00)$ \\
\hline 20 & Polymer & 40 & $0(0.00)$ \\
\hline 50 & Polymer & 40 & $0(0.00)$ \\
\hline 100 & Paper & 40 & $12(30.00)$ \\
\hline 200 & Paper & 40 & $10(25.00)$ \\
\hline 500 & Paper & 40 & $7(17.50)$ \\
\hline 1000 & Paper & 40 & $3(7.50)$ \\
\hline Total $(\%)$ & & 320 & $32(10.00)$ \\
\hline
\end{tabular}

\section{Prevalence of Parasites in Relation to Currency Sources}

Naira notes collected from butchers had the highest prevalence of parasitic contamination 11 (17.19\%) followed by food vendors 9 (14.06\%), fish sellers 8 (12.50\%) hawkers 3 (4.69\%) while those from fruits and vegetable sellers $1(1.56 \%)$ had the least parasitic contamination (Table 4). Therefore, there was a high significant difference $\left(\chi^{2}=17.386, \mathrm{df}=4, \mathrm{P}=0.001626\right)$ in the level of contamination of the Naira notes in relation to currency sources.
Table 4: Prevalence of parasitic contamination in relation to currency sources.

\begin{tabular}{|c|c|c|}
\hline Source of N currency & No. examined & No. contaminated (\%) \\
\hline Food vendors & 64 & $9(14.06)$ \\
\hline $\begin{array}{c}\text { Fruits and vegetables } \\
\text { sellers }\end{array}$ & 64 & $1(1.56)$ \\
\hline Butchers & 64 & $11(17.19)$ \\
\hline Fish sellers & 64 & $8(12.50)$ \\
\hline Hawkers & 64 & $3(4.69)$ \\
\hline Total (\%) & $\mathbf{3 2 0}$ & $\mathbf{3 2}(\mathbf{1 0 . 0 0 )}$ \\
\hline
\end{tabular}

\section{Discussion}

This is the first study in Lafia, Nasarawa State that showed that the Nigerian currency notes in circulation within the metropolis are contaminated with five parasite species as shown on the checklist (Table 1) that are known to be pathogenic to humans. This is in agreementt with studies conducted in other parts of Nigeria who reported similar findings [7,8,15-19]. The $10.00 \%$ parasites contamination recorded in the circulating notes in this study implies that the notes are a bit cleaner in comparison to the findings of Matur et al. [16], Ahmed and Mujittapha [7], Leonard and Olajumoke [8] and Nasiru et al. [18] who recorded a slightly higher parasitic contamination of $32.0 \%, 14.0 \%, 21.9 \%$ and $12.04 \%$ prevalence in the Federal Capital Territory, Abuja; Kastina metropolis, Kastina State; Ibadan city in Oyo State; and Dustinma metropolis in Kastina State respectively. Of the checklist of parasites generated, hookworm was the most prevalent parasite in the Naira currency notes probably due to high chances of the notes falling on the ground surface and as well as the possibility of users using soiled hands to handle these notes. Correspondingly, studies on parasites, cyst and egg on the Nigerian currency by Ombugadu et al. [20] indicated that hookworm was the most prevalent parasites screened from currency notes sourced within Keffi metropolis, Nasarawa State. 
The very dirty notes were the most contaminated with parasites probably due to the fact that they had been in circulation for long and exchanged hands more frequently thus exposed to contamination. This agrees with findings of Ahmed and Mujittapha [7], Simon-oke and Ajileye [19] and Ombugadu et al. [20] who reported that the very dirty notes collected from Katsina, Akure and Keffi metropolis were the most contaminated with parasites. However, this is contrary to the finding of George and Ifenyinwa [21] in a study in Akure metropolis who reported that the dirty notes were the most contaminated with parasitic contaminants. The $\$ 100$ denomination notes were the most contaminated with parasites possibly due to the fact that it is commonly at the reach of most people at the lower income group in the populace than the $\$ 1000$-notes. This implies that the $\$ 100$ denomination passes more hands and gets contaminated in the process than the $\$ 1000$ notes which is not handled by many people. This finding is in agreement with the reports of earlier works of Leonard and Olajumoke [8] and Simon-oke and Ajileye [19] who found that the \#100 notes carried more contaminants. On the other hand, the present observation does not agree with the finding of Ahmed and Mujittapha [7] who noted that the $\$ 200$ denomination notes were the most contaminated.

From this study, it was observed that a number of the paper notes were contaminated with parasites whereas the polymer notes were parasite free. This may be as a result of the rough surface of the paper notes which probably promotes a good attachment area for the parasites whereas polymer notes has a smooth and slippery surface which will not support adherence of the parasites. El-Dars and Hassan [22] had opined that paper notes which are made of $75 \%$ cotton and $25 \%$ linen offer large surface area for pathogen attachment. Also, Dehghani et al. [23] reported that the degree of contamination is dependent on the texture of the currency. Similarly, this observation is in agreement with Leonard and Olajumoke [8] who recorded parasites on paper notes while none was found on polymer notes screened. On the contrary, the findings of Ahmed and Mujittapha [7], Ombugadu et al. [20] and Simon-oke and Ajileye [19] recorded high parasites prevalence in polymer notes. The very high prevalence rate of parasites in naira notes handled by Butchers may possibly be due to the nature of their job in which they handle meats (gastrointestinal parts) of various animals that might have been infected with parasites. This supports the findings of the studies in Dutsin-ma and Akure metropolis where currency notes handled by butchers were highly contaminated $[18,19]$. The contamination of notes obtained from food vendors and fish sellers ranked second and third respectively. This suggests that these sources are fun of unhygienic practices in relation to notes handling. For instance, food vendors often times handle money while they serve food at the same time to their customers. Previous works by FSA [24] and El-Dars and Hassan [22] suggests that simultaneous handling of food and money contributes and may as well cause sporadic food borne-diseases.

\section{Conclusion}

Findings from this study have shown that circulating Naira notes in Lafia metropolis were contaminated irrespective of currency sources and notes types. With the exception of mints, the physical conditions of all other Naira notes accommodate parasites on them. Paper notes harbor parasites while no polymer note was contaminated. The $\$ 100$ notes were the most contaminated denomination of the Naira notes screened. It is therefore recommended that public health education and awareness campaign to the populace of Lafia metropolis should be carried out focusing on the health benefits of good personal hygiene and the high possibility of acquiring infections while handling Naira notes. Also, the change of paper notes denominations ( $\$ 100$, $\$ 200, \$ 500, \$ 1000$ ) into polymer notes will drastically reduce the prevalence rate of parasites in Naira notes. Food vendors should have separate cashier that strictly handle collection of funds so as to reduce chances of the falling off of parasites into food being served to consumers in the process of collection of Naira notes if the individual dishing out the food is simultaneously the cashier.

\section{References}

1. Uneke C, Ogbu $\mathrm{O}$ (2007) Potential for parasite and bacterial transmission by paper currency in Nigeria. Journal of Environmental Health 69(9): 54-60.

2. Basavarajappa KG, Rao KN, Suresh K (2005) Study of bacterial, fungal and parasitic contamination of currency notes in circulation. Indian Journal of Pathology and Microbiology 48(2): 278-279.

3. Umeh E, Juluku J, Ichor T (2007) Microbial contamination of Naira (Nigerian Currency) notes in circulation. Research Journal of Environmental Sciences 1(6): 336-339.

4. Bhat N, Bhat S, Asawa K, Agarwal A (2010) An assessment of oral health risk associated with handling of currency notes. International Journal of Dental Clinics 2(3): 188-193.

5. Uraku AJ, Obaji PI, Nworie A (2012) Potential risk of handling Nigerian currency notes. International Journal of Advanced Biological Research 2(2): 228-233

6. Orji N, Esiaka E, Anyaegbunam L, Obi R, Ezeagwuna D (2012) Parasite contamination of Nigerian currency (Paper and polymer notes) in the Ihiala Local Government Area of Anambra State, Nigeria. The Internet Journal of Infectious Diseases 10: 1-5.

7. Ahmed A, Mujittapha A (2015) Prevalence of parasite eggs and cysts on the Naira notes in katsina metropolis. Kastina Journal of Natural and Applied Sciences 4(1): 61-69

8. Leonard OA, Olajumoke M (2016) Parasite contamination of Nigeria currencies in Ibadan city, South-west Nigeria. Annual Research and Review in Biology 10(6): 1-6.

9. Badvi JA, Jawed K, Jawed M (2017) Lower denomination and dirty currency carries more contamination than higher denomination in Pakistan. International Journal of Vaccines and Vaccination 4(3): 1-8.

10. Neel GR, Marcelline U, Izere C, John KK (2018) Contamination of currency notes and coins as sources of transmissible diseases. International 
Journal of Pharmaceutical Research and Health Sciences 6(1): 23342337.

11. AL Ghamdi AK, Abdelmalek SMA, Bamaga MS, Azharl EI, Wakid MH, et al. (2011) Bacterial contamination of Saudi "one" Riyal paper notes. Southeast Asian Journal of Tropical Medicine and Public Health 42(3): 711-716.

12. Awodi NO, Nock IH, Aken Ova I (2000) Prevalence and Public Health Significance of parasitic cysts and eggs on the Nigeria Currency. The Nigerian Journal of Parasitology 22: 137 -142.

13. (2006) National Population Commission. The National population and National Bureau of Statistic estimates. Population forcasts.

14. Daniel B, Obadiah B (2013) The emerging central business district (CBD) in Lafia town, Nigeria, and it related urban planning problems. International Journal of Industrial and System Engineering 7(3): 568573.

15. Ogo NI, Ayayi OO Madukeke A (2004) Eggs and cysts of parasite contaminating Nigerian Currency notes. African Journal of Natural Science 7: 40-42.

16. Matur BM, Malann YD, Edhomeriegue Y (2010) A Survey of Parasite Cysts, Eggs and Bacteria on Nigerian Currency in FCT, Abuja. New York Science Journal 3 (1): 10-13.

17. Okwa 00, Bello SA (2016) Parasitic organisms on Nigerian currency notes in Ojo local government, Lagos, Nigeria. International Journal of Pure and Applied Zoology 4(2): 221-224.

ISSN: 2574-1241

DOI: 10.26717/BJSTR.2021.34.005557

Attah A S. Biomed J Sci \& Tech Res

(c) (P) This work is licensed under Creative

Submission Link: https://biomedres.us/submit-manuscript.php
18. Nasiru M, Nuhu I, Bawa JA (2017) Microbes associated with currency Notes in circulation within Dutsin ma metropolis, Katsina state, Nigeria. FUDMA Journal of Sciences 1(1): 123-127.

19. Simon Oke IA, Ajileye OD (2019) Evaluation of parasites as contaminants of currency notes in Akure, Nigeria. International Journal of Enteric Pathogens 7(2): 44-48.

20. Ombugadu RJ, Tongjura JDC, Hassan SC, Ajuzie U (2019) A survey of parasites cysts and eggs (ova) on Nigerian currency notes in Keffi; Nasarawa state, Nigeria. FUW Trends in Science and Technology Journal 4(1): 83-85.

21. George UI, Ifenyinwa JE (2019) Currency notes and associated risk of neglected tropical diseases: Study on the Nigerian Naira. International Journal of Research-Ganthaalayah 7(12): 252-258.

22. El Dars FM, Hassan WM (2005) A preliminary bacterial study of Egyptian paper money. International Journal of Environmental Health Research 15(3): 235-239.

23. Dehghani M, Dehghani V, Estakhr J (2011) Survey of Microbial Contamination of Iranian Currency Papers. Research Journal of Pharmaceutical, Biological and Chemical Sciences 2(3): 242-248.

24. (2000) Food Science Australia. Money Handling in Food Service Operations. Food Safety and Hygiene. A bulletin for the Australian Food Industry.

$\begin{array}{ll}\text { BIOMEDICAL } & \text { Assets of Publishing with us } \\ \text { RESEARCHES } & \text { - Global archiving of articles } \\ \text { - Immediate, unrestricted online access } \\ \text { - Rigorous Peer Review Process } \\ \end{array}$

